Research Report No. 10/2011

\title{
A Surfer's Guide to US Foreign Policy in Egypt, or Has Obama Been Snookered?
}

Craig Scott

Osgoode Hall Law School of York University

Follow this and additional works at: http:// digitalcommons.osgoode.yorku.ca/clpe

\section{Recommended Citation}

Scott, Craig, "A Surfer's Guide to US Foreign Policy in Egypt, or Has Obama Been Snookered?" (2011). Comparative Research in Law \& Political Economy. Research Paper No. 10/2011.

http://digitalcommons.osgoode.yorku.ca/clpe/48 


\section{OSGOODE}

OSGOODE HALL LAW SCHOOL

YOR K U N I VERSITY

\section{OSGOODE HALL LAW SCHOOL}

Comparative Research in Law \& Political Economy

RESEARCH PAPER SERIES

Research Paper No. 10/2011

\section{A Surfer's Guide to US Foreign Policy in Egypt, or Has Obama Been Snookered?}

Craig Scott

\section{Editors:}

Peer Zumbansen (Osgoode Hall Law School, Toronto, Director, Comparative Research in Law and Political Economy)

John W. Cioffi (University of California at Riverside)

Lisa Philipps (Osgoode Hall Law School, Associate Dean Research)

Nassim Nasser (Osgoode Hall Law School, Toronto, Production Editor)

Comparative Research in Law \& Political Economy 
Osgoode CLPE Research Paper 10/2011

Vol. 07 No. 04 (2011)

Craig Scott

\title{
A Surfer's Guide to US Foreign Policy in Egypt, or Has Obama Been Snookered?
}

\begin{abstract}
This short article (3800 words, including 14 footnotes) was written and published on February 8,2011 , by OpenDemocracy.net, and may be republished with attribution for noncommercial purposes following the Creative Commons guidelines. OpenDemocracy.net's summary blurb reads: "Reading the Washington runes. What happened with Mr Wisner, Egypt lobbyist and Obama's special envoy to Mubarak? Is this an ugly farce, an ethical travesty or a cronyistic scandal?" The purpose of the article is to explore two hypotheses surrounding the sending by President Obama of former US Ambassador to Egypt, Frank Wisner, as Obama's envoy to President Hosni Mubarak of Egypt during the period of post-January 25, 2011, revolutionary activity in Egypt. One hypothesis explores the possibility that Secretary of State Hillary Clinton's role amounted to an outflanking of President Obama's preferred messaging on Egypt, inter alia, through the recommendation of Wisner as messenger. The second hypothesis is that Clinton and Obama have been in lockstep in arriving at what I refer to as the Suleiman Transition (referencing Omar Suleiman as Mubarak's newly appointed Vice-President). It is recognized that neither hypothesis can be shown to be true on current information at the time of writing, and accordingly argued that Clinton, Obama and Wisner need to answer a series of specified questions about how Clinton and Obama interacted since the start of the January 25, 2011, Egyptian revolution, specifically in relation to the Wisner role.
\end{abstract}

Key words: Egypt, Hosni Mubarak, Hillary Rodham Clinton, Barack Obama, United States, Frank Wisner, Omar Suleiman, ethics, political accountability, realpolitik, foreign policy, human rights, torture, democracy, international politics, international relations

Jel Classification: K39

\author{
Craig Scott \\ Professor of Law, \\ Osgoode Hall Law School of York University, \\ Toronto; \\ Director (on leave, 2010-2011), \\ Nathanson Centre on Transnational Human Rights, Crime and Security
}




\title{
A Surfer's Guide to US Foreign Policy in Egypt, or Has Obama Been Snookered?
}

\author{
Craig Scott*
}

Think of the present article as a (web) surfer's guide to one tiny corner of this messed-up galaxy.

If you had a chance to read "Taking Tea with Torturers" on OpenDemocracy.net (January 31), you will recall that the title references Lady Thatcher's friendship with Pinochet as an entrypoint to discussing Secretary of State Hillary Clinton's relationships with Egypt's Mubarak and the Foreign Minister of Sri Lanka. "Taking Tea with Torturers" ended as follows: "Secretary of State Clinton's family ties become part of her political accountability. As such, Clinton - and by extension President Obama - need to find a way to create critical distance between her friends and the foreign policy of the United States." My purpose now is to suggest that my concern on January 31 about Hillary Clinton's capacity to engage ethically on the Egypt file may well have been on the mark, in light of developments since then - or, at the very least, she has questions to answer. Alternatively, and as I will discuss at the conclusion, Clinton's compromises may have been adopted - in full knowledge and completely willingly - as President Obama's own although the outward signs do not seem to fully jive with such an in-sync handling of Egypt by Obama and Clinton. The ultimate point is that questions need to be asked - including by the mainstream media - about how Clinton and Obama have interacted since the start of the January 25 Egyptian revolution.

Those who read "Taking Tea with Torturers" may also recall that I referenced a memorytwigging notice published on the American Independent website, about Secretary of State Clinton's unguarded and indeed enthusiastic statement to the Egyptian media, in 2009, that she was personally close to the Mubaraks. This was Luke Johnson, "Sec. Clinton interview in March 2009 marginalizes human rights, says Mubaraks are 'friends of the family'" (January 28,

\footnotetext{
This piece was written on February 8, 2011, and published the same day by OpenDemocracy.net which is the official, published version: cite as Craig Scott, "A Surfer's Guide to US Foreign Policy in Egypt, or Has Obama Been Snookered?", (February 8, 2011) OpenDemocracy.net, available for download at http://www.opendemocracy.net/craig-scott/surfer\%E2\%80\%99s-guide-to-us-foreign-policy-in-egypt-or-hasobama-been-snookered. It may be republished with attribution for non-commercial purposes following the Creative Commons guidelines. The present SSRN PDF working-paper version will retain its usefulness with respect to ease of reference to the footnotes that correspond to the hyperlinks in the online published article.

* The author is Professor of Law, Osgoode Hall Law School, Toronto, and Director, Nathanson Centre on

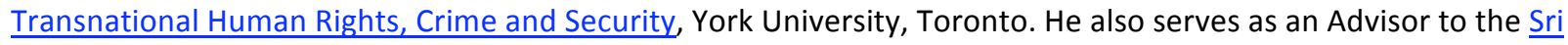
Lanka Campaign for Peace and Justice. He is also presently an Ikerbasque Fellow in Bilbao, based at the Universidad de Deusto, and Commissioner with the civil-society Comisión de Verdad (Truth Commission) in Honduras.

${ }^{1}$ Craig Scott, "Taking Tea with Torturers", (January 31, 2011) OpenDemocracy.net, available for download at http://www.opendemocracy.net/craig-scott/taking-tea-with-torturers and also at http://papers.ssrn.com/sol3/papers.cfm?abstract id=1752889.
} 
2011, AmericanIndependent.com). ${ }^{2}$ For the full transcript of the 2009 interview by Al Arabiya TV in Egypt, during which she made these observations, see Randa Aboul Azem (Al Arabiya Television), "Interview: Hillary Rodham Clinton, Secretary of State - Sharm el-Sheikh, Egypt" (March 2, 2009). ${ }^{3}$

Now, jump ahead to February 2, last Wednesday. Politico.com's Laura Rozen reports (“U.S. Egypt envoy recalled, as Clinton calls violence 'shocking'") as follows: "The Obama White House's Egypt troubleshooter, former U.S. Amb. to Egypt Frank G. Wisner, abruptly returned to Washington from Cairo Wednesday, as violence sharply escalated and pro-regime mobs attacked demonstrators demanding Hosni Mubarak step down. Wisner, sent to Cairo Sunday at the suggestion of Hillary Clinton, found his conversations with Egyptian officials no longer useful, ABC News reported, supposedly after reports disclosed his meeting with Mubarak to persuade him to depart. He also met with Egyptian Vice President Omar Suleiman." ${ }^{4}$ According to Jake Tapper's, whose ABC report is what Rozen referenced in her report on Politico.com, "Wisner, the former Ambassador to Egypt during the Reagan and Bush Sr. administrations, was sent to Cairo on Sunday at the suggestion of Secretary of State Hillary Clinton because of his close relationship with Mubarak. But their back-channel conversations became no longer useful, an administration official said, after they found their way into the media." (Jake Tapper, "President Obama 'Very Concerned' About Mubarak Delaying Transfer Of Power", Feb 2, 2011. $)^{5}$ So, what surfing has yielded as of February 2 is that Hillary Clinton recommended Frank Wisner to go to Egypt to convey a message from the President "to persuade [Mubarak] to depart" and that "supposedly" (this being Laura Rozen's qualifier) Wisner's mission ended when reports of his discussions leaked to the media.

By this past weekend - that is, by Saturday, February 5 - we begin to see that Politico.com's Laura Rozen's may have been prescient in her cautious use of the word "supposedly" in her report. ABC's Jake Tapper now reports (again, this past Saturday) in his piece "Obama Administration Distances Self From Own Envoy to Mubarak" as follows: "The Obama

${ }^{2}$ Luke Johnson, "Sec. Clinton interview in March 2009 marginalizes human rights, says Mubaraks are 'friends of the family'" (January 28, 2011) AmericanIndependent.com, available for download at

http://www.americanindependent.com/167486/sec-clinton-interview-in-march-2009-marginalizes-human-rightssays-mubaraks-are-friends-of-the-family.

${ }^{3}$ Randa Aboul Azem, "Interview: Hillary Rodham Clinton, Secretary of State - Sharm el-Sheikh, Egypt" (March 2, 2009) Al Arabiya Television, available for download at http://www.state.gov/secretary/rm/2009a/03/120115.htm.

${ }^{4}$ Laura Rozen, “U.S. Egypt envoy recalled, as Clinton calls violence 'shocking'” (February 2, 2011) Politico.com, available for download at http://www.politico.com/blogs/laurarozen/0211/Report Obama Egypt envoy Wisner recalled to DC.html.

5 Jake Tapper, "President Obama 'Very Concerned' About Mubarak Delaying Transfer Of Power", (Feb 2, 2011) Political Punch Blog, $A B C$ News, available for download at http://blogs.abcnews.com/politicalpunch/2011/02/president-obama-very-concerned-about-mubarak-delayingtransfer-of-power.html. 
administration on Saturday distanced itself from comments about Egyptian President Hosni Mubarak made by a man the president had used as an envoy to Mubarak just days before. Saying he was speaking for himself, former U.S. Ambassador to Egypt Frank Wisner said at a security conference in Munich, Germany, that 'President Mubarak remains utterly critical in the days ahead as we sort our way toward the future.' Wisner said that Mubarak 'must stay in office in order to steer those changes through. ... This is an ideal moment for him to show the way forward."' 6 So, by February 5, the web surfer discovers that, a scarce few days after having his envoyship ended, Wisner has publicly stated a position that is not what the White House had led journalists to believe was the message Obama had sent Wisner to convey to Mubarak. Could it be that Wisner was recalled not because the media had learned of his role but because President Obama realized Wisner had been off-message when meeting Mubarak? Even assuming, to be the most charitable possible to all involved, that this was 'merely' an egregious case of 'broken telephone' - in this case, a seasoned diplomat simply having misheard the message to be delivered - did Wisner 'mishear' Obama or was it Clinton who briefed or instructed him on the message to be conveyed?

For this lowly web surfer, the final connecting of the dots came the next day - Sunday, February 6 - when Juan Cole, on his essential Middle East blog JuanCole.com, wondered why President Obama would choose to send to Egypt, as his informal envoy, someone (Wisner) who is "a paid lobbyist for Egypt." (Juan Cole, "Egypt: I ask Myself Why", February 6, 2011.) What? Come again? I immediately starting surfing madly, wipe-out be damned, and came across a recent profile being, dated February 2, by the New York Times ("Frank Wisner, the Diplomat Sent to Prod Mubarak") . ${ }^{8}$ Let's see, Frank Wisner, career diplomat who is compared to Richard Holbrooke in terms of his gravitas within the US foreign policy apparatus, albeit a less flashy Holbrooke and someone who does not crave the limelight. Four ambassadorships, a key role in negotiations around Kosovo, and a public warning to George W Bush not to go to war against Iraq. Why wouldn't a President send a fellow like that to "'deliver some hard messages'" (this being the description of Wisner's role as stated to the New York Times by Leslie $\mathrm{H}$. Gelb, the former diplomat and journalist who co-founded a lunch club with Mr. Wisner)? But, I returned to Juan Cole's reference to Wisner as a "paid lobbyist for Egypt" when I read one sentence in this New York Times article: "For more than a decade, [Wisner] was vice chairman of the insurance giant A.I.G.; he left in 2009, just as the company was getting bailed out by American taxpayers, and joined the lobbying firm Patton Boggs." It was late in Europe, where this surfer is currently based, so he went to sleep hoping to find out more about Patton Boggs the next day.

\footnotetext{
${ }^{6}$ Jake Tapper, “Obama Administration Distances Self From Own Envoy to Mubarak”, (Feb 2, 2011) Political Punch Blog, $A B C$ News, available for download at http://blogs.abcnews.com/politicalpunch/2011/02/president-obamavery-concerned-about-mubarak-delaying-transfer-of-power.html.

7 Juan Cole, "Egypt: I ask Myself Why", (February 6, 2011) JuanCole.com, available for download at http://www.juancole.com/2011/02/egypt-i-ask-myself-why.html.

${ }^{8}$ Sheryl Gay Stohlberg, "Frank Wisner, the Diplomat Sent to Prod Mubarak" (February 2, 2011) New York Times, available for download at http://www.nytimes.com/2011/02/03/world/middleeast/03wisner.html? r=1.
} 
The next day, yesterday, Monday, February 7, The Independent's Robert Fisk puts an exclamation mark on Juan Cole's final dot with his exposé called "US envoy's business link to Egypt" (www.independent.co.uk, Feb 7, 2011). ${ }^{9}$ The entire, quite detailed piece is a crucial read, but here are some passages from Fisk's analysis for immediate consideration, to stimulate your interest to read more: "Frank Wisner, President Barack Obama's envoy to Cairo who infuriated the White House this weekend by urging Hosni Mubarak to remain President of Egypt, works for a New York and Washington law firm which works for the dictator's own Egyptian government....The litigation firm Patton Boggs ... openly boasts that it advises 'the Egyptian military, the Egyptian Economic Development Agency, and has handled arbitrations and litigation on the [Mubarak] government's behalf in Europe and the US.' ...[I]t is inconceivable Hillary Clinton did not know of his employment by a company that works for the very dictator which Mr Wisner now defends in the face of a massive democratic opposition in Egypt. So why on earth was he sent to talk to Mubarak, who is in effect a client of Mr Wisner's current employers?... A spokesman for the State Department said he 'presumed' Mrs Clinton knew of Mr Wisner's employment by Patton Boggs and the firm's links with the Mubarak government, but refused to comment on any conflict of interest for the envoy."

It is hard to know whether this sequence of events is better characterized as an ugly farce or as an ethical travesty or as a cronyistic scandal, but it does rather seem that Secretary of State Clinton has a lot of explaining to do. At minimum, on the face of it, it certainly does not help a President when his point person on foreign policy recommends someone of Wisner's compromised background to take the President's move-on-now message (if that was in fact Obama's message) to Mubarak - someone (Wisner) who would know how deeply and seriously he would undermine the President if he deliberately spoke out at a security conference to say that Mubarak needs to stay. A jaded observer of all this, knowing how Hillary Clinton had enthused about Mubarak as a friend of her family and assuming that she had to have known Wisner's great and unseemly conflict of interest, might be inclined to wonder at least a couple things: one, whether she and the President were on the same page when Wisner was briefed about what his message to Mubarak was to be and, two, whether she even in advance that Mr Wisner was going to come out in Munich and say that Mubarak "must stay in office."

Of course, an alternative interpretation needs to be considered, one that does not cast Clinton as the Machiavellian. It is always possible in the so-often-so-deceitful world of politics, especially international politics, that Clinton and Obama have been in perfect lockstep - i.e. that Obama sent Wisner in full knowledge of his compromised interests as a member of Egypt's lobbying and PR firm in the US but having made the calculation that someone so close to Mubarak could 'sell' the message from the President, if anyone could. Along the same lines, Obama may even have been asking Clinton to leverage the fact the Mubaraks are "friends of

\footnotetext{
${ }^{9}$ Robert Fisk, "US envoy's business link to Egypt" (Feb 7, 2011) The Independent, available for download at . http://www.independent.co.uk/news/world/americas/us-envoys-business-link-to-egypt-2206329.html.
} 
my [Clinton's] family" to engage in back-channel calls to Mubarak - which, if they have taken place, have not yet leaked to the media. On this alternative interpretation, Obama has willingly and fully been playing a game that combines odium (support for Suleiman) with a measure of deceit, in that the public messaging (or at least the impression deliberately left) around the time of Wisner's deployment was that the President's view was that Mubarak himself needed to leave before the scheduled September elections. Viewed from this hypothetical perspective, the reason the White House was furious at Wisner for his public statements at Munich (that Mubarak must stay) would be precisely because the statements were public: Wisner's misstep was, on this hypothesis, thus not that we went off-message in terms of substance but rather that he spoke out of turn by revealing publicly what Obama and Clinton had indeed asked him to say privately. Thus, the White House and the President would now be engaging in dissembling as they disavow Wisner's remarks as those in Wisner's private capacity, in order to create the impression that Wisner's substantive message was not that of the President.

Adding support to the foregoing Clinton-and-Obama-as-Machiavellian-partners-in-arms hypothesis is that we must assume, of course, that President Obama is his own person and that he is fully responsible for his decisions around Egypt. Such decisions include his lining up behind Mubarak's former head of Intelligence and torturer-in-chief, Omar Suleiman, as the man to lead the transition (whatever Obama understands by that). See especially an insightful article by the University of California's Lisa Hajjar, "Suleiman: The CIA's man in Cairo" (AlJazeera.net, Feb 7, 2011). ${ }^{10}$ Hajjar details Suleiman's role as anti-democrat, his role as cog in the US's rendition-totorture system that started under Bill Clinton (when the system was supposed to be renditionto-trial but conveniently relied on worthless assurances from Egypt that persons handed over would not be tortured) and that was ramped up under George W Bush, and indeed his role as not just overseer of a torture system but also as a hands-on torturer. Hajjar also discusses Suleiman's other attributes: "Suleiman has long been favoured by the US government for his ardent anti-Islamism, his willingness to talk and act tough on Iran - and he has long been the CIA's main man in Cairo. Mubarak knew that Suleiman would command an instant lobby of supporters at Langley and among 'Iran nexters' in Washington - not to mention among other authoritarian mukhabarat-dependent regimes in the region. Suleiman is a favourite of Israel too; he held the Israel dossier and directed Egypt's efforts to crush Hamas by demolishing the tunnels that have functioned as a smuggling conduit for both weapons and foodstuffs into Gaza."

In the context of blessing Suleiman (or being 'forced' to do so if this was Mubarak's own canny decision to elevate Suleiman), it is not unlikely that President Obama has been constantly hearing arguments such as that advanced by Israeli historian Benny Morris in the Guardian that the Muslim Brotherhood's aim is to win elections and then get rid of democracy itself - a plan Morris presents as a certainty versus as the possibility others worry about: see "The West must

\footnotetext{
${ }^{10}$ Lisa Hajjar, "Suleiman: The CIA's man in Cairo" (February 7, 2011) AlJazeera.net, available for download at http://english.aljazeera.net/indepth/opinion/2011/02/201127114827382865.html.
} 
be wary of Egypt's Muslim Brotherhood" (Guardian.co.uk, Feb 3, 2011). ${ }^{11}$ Morris likens the current situation to Russia's Communist Revolution, an analogy one imagines he knows will resonate well in the ever-communist-fearing US: "No doubt [former IAEA head Mohamed ElBaradei's] behaviour appealed to Egypt's Islamists. But ElBaradei is western-educated and appears to be a secularist, and he is likely to be shunted aside by the religious fanatics once they feel confident enough to emerge from the shadows. ElBaradei will then have filled the role of the Mensheviks, who paved the way for the eventual Bolshevik takeover of Russia in 1917." (Perhaps Morris assumes Americans will draw their own analogies to the manner in which the provisional government following the Shah's departure from Iran was taken over by Ayatollah Khomeini and an Islamic-state system, as he does not bring that analogy up.) All of this is to say that it is plausible both that Obama has been surrounded by such arguments and that he may be swayed by such arguments notwithstanding good reason to believe they misunderstand the nature of this revolution, the behavior for the last 50 years of the Brotherhood, and the general context within which any seizure of power by the Brotherhood would need to fit: for counterviews to Morris, consider the eye-opening analysis of University of Illinois professor Asef Byat, "Egypt, and the post-Islamic Middle East" published on OpenDemocracy.net earlier today (February 8, 2011) and see also Richard Bulliet, "Time to end US fear of Muslim Brotherhood" in the Guardian Online (Feb 3, 2011). ${ }^{12}$

Further in favour of the hypothesis that Clinton and Obama have been in lockstep is the fact that Obama seems to have 'Compromise' as his second middle name (sometimes a virtue, sometimes not) and that there is plenty of evidence that Obama is not adverse to taking decisions that are based on a muscular, if not militaristic, view of US prerogatives in the world. We can think of his Administration's escalation of targeted killings as a preferred counterterrorism strategy in the post-Bush struggle against Al-Qaeda, the Taliban, and, most crucially, others who had no connection to 9/11. See Karen DeYoung and Joby Warrick, "Under Obama, more targeted killings than captures in counterterrorism efforts", WashingtonPost.com (Feb 14, 2010) and "Human Rights Watch, "Letter to Obama on Targeted Killings and Drones" (December 7, 2010). ${ }^{13}$ Or, we can think back to the US' abandonment of key South American

\footnotetext{
${ }^{11}$ Benny Morris, "The West must be wary of Egypt's Muslim Brotherhood" (Feb 3, 2011) Guardian Online, available for download at http://www.guardian.co.uk/commentisfree/2011/feb/03/egypt-muslim-brotherhood-westdemocracy?INTCMP=SRCH.

${ }^{12}$ Asef Byat, "Egypt, and the post-Islamic Middle East", February 8, 2011) OpenDemocracy.net, available for download at http://www.opendemocracy.net/asef-bayat/egypt-and-post-islamist-middle-east; Richard Bulliet, "Time to end US fear of Muslim Brotherhood" (February 3, 2011) Guardian Online, available for download at http://www.opendemocracy.net/asef-bayat/egypt-and-post-islamist-middle-east.

${ }^{13}$ See Karen DeYoung and Joby Warrick, "Under Obama, more targeted killings than captures in counterterrorism efforts", (Feb 14, 2010) Washington Post, available for download at http://www.washingtonpost.com/wpdyn/content/article/2010/02/13/AR2010021303748.html; Kenneth Roth, "Letter to Obama on Targeted Killings and Drones" (December 7, 2010) Human Rights Watch, available for download at http://www.hrw.org/en/news/2010/12/07/letter-obama-targeted-killings.
} 
states like Brazil and Argentina that were seeking to respond firmly and with a united interstate front to the coup in Honduras, when the US immediately recognized the results of the November 2009 post-coup elections in Honduras notwithstanding region-wide concerns about the manner and context in which they had taken place: see Universidad Iberoamericana Professor Thomas Legler's detailed scholarly conference paper, "Coup Coalitions and the Collective Defence of Democracy in the Americas: The Honduran Paradox" (October 2010). ${ }^{14}$ There is thus much to an argument that, under Obama, US foreign policy shows continuity more than any serious discontinuity between the Bush and Obama eras. And, so, against that backdrop, it is far from unimaginable that Obama fully and freely chose realpolitik over a moral posture on Egypt - or, more charitably to him, chose to meld the two into the best middle ground he felt he had to tread, whether called a "stable transition" or an "orderly transition."

These examples may well have had something - or, more likely, a lot - to do with Clinton's views and influence as Secretary of State. But saying that Clinton has been key is nothing more than saying she has been a forceful and politically adept Secretary of State. This is very different from saying Clinton has actually outflanked Obama and implemented her own policy against the President's wishes - which is what is at stake in wondering whether an outflanking of Obama resulted from Clinton's closeness to Mubarak and her role in sending to Cairo someone so in bed with Mubarak and the Egyptian state.

Still, on the facts as they have emerged, it seems to me that the burden is on Hillary Clinton to explain how it is that she has served the President well in this whole fiasco. At the same time, and possibly even more so, President Obama has explanations to give. Between the two of them, we need each to answer the following questions-and Frank Wisner also needs to be held to public account by being asked these same questions.

Did President Obama send Wisner as his envoy in full knowledge of Wisner's employment at Patton Boggs, or was that fact elided by Clinton when recommending Wisner to the President? Was Wisner briefed orally or with papered instructions, and were those oral or papered instructions direct from the President or from Secretary of State Clinton? Did Wisner deliver the message President Obama charged him with conveying to Mubarak, or not, and what was that message, exactly? Was Wisner recalled from Cairo because of leaks of his role or because President Obama, or perhaps Secretary of State Clinton, learned of or suspected he had been off-message? Has Hillary Clinton been pursuing her own direct back channel with Mubarak or Suleiman, and with what messages? Did the idea of appointing Suleiman Vice-President and transitioner-in-chief emerge from discussions involving Wisner and/or Clinton with Mubarak or did the Egyptians come up with this move to snooker the US on their own? If Wisner or Clinton did discuss the Suleiman elevation, was this with the concurrence of the President or did the President learn of this Mubarak move only when it was made? How is it that someone

\footnotetext{
${ }^{14}$ Thomas Legler, "Coup Coalitions and the Collective Defence of Democracy in the Americas: The Honduran Paradox", Paper prepared for delivery at the 2010 Congress of the Latin American Studies Association, Toronto, Canada October 6-9, 2010, available for download at http://lasa.international.pitt.edu/members/congresspapers/lasa2010/files/1768.pdf.
} 
(Wisner) so versed in foreign relations and just coming off the most crucial of missions for the President could publicly state a position diametrically opposed to what the White House claims to be its own position? Did Clinton know in advance what Wisner was going to say or even actively encourage Wisner's remarks?

Based on what we know now, by recommending Frank Wisner to be the President's envoy to Cairo, Clinton could not have snookered Obama better if she had tried. The bigger question is whether this is in fact exactly what she tried - and also whether she has, in the result, succeeded given how the US seems to have lined up behind the Suleiman Transition as 'solution.' 